\title{
UJI AKTIVITAS ANTIBAKTERI PASTA GIGI EKSTRAK BIJI PINANG (Areca catechu L.) TERHADAP Streptococcus mutans DAN Staphylococcus aureus
}

\section{ANTIBACTERIAL ACTIVITY TEST of TOOTHPASTE OF BETEL NUT (Areca catechu L.) EXTRACT AGAINST Streptococcus mutans AND Staphylococcus aureus}

\author{
Nur Afni ${ }^{1}$, Nasrah Said ${ }^{1}$, Yuliet ${ }^{2}$. \\ ${ }^{1}$ Program Studi Farmasi, Sekolah Tinggi Ilmu Farmasi (STIFA) - Pelita Mas, Palu \\ ${ }^{2}$ Jurusan Farmasi, Fakultas MIPA, Universitas Tadulako, Palu
}

Received 28 Januari 2015, Accepted 27 Februari 2015

\begin{abstract}
ABSTRAK
Biji pinang (Areca catechu L.) merupakan bahan alam yang memiliki aktivitas antibakteri diantaranya terhadap Streptococcus mutans dan Staphylococcus aureus. Berdasarkan hal tersebut maka biji pinang diformulasikan dalam sediaan pasta gigi yang memiliki aktivitas sebagai antibakteri. Penelitian ini bertujuan untuk mengetahui aktivitas antibakteri pasta gigi ekstrak biji pinang dengan variasi konsentrasi $1,5 \%, 3 \%$ dan 4,5\% dan untuk mengetahui konsentrasi efektif ekstrak biji pinang dalam pasta gigi yang memenuhi mutu fisik kimia dan memiliki aktivitas antibakteri terhadap Streptococcus mutans dan Staphylococcus aureus. Rancangan penelitian yang digunakan adalah Rancangan Acak Lengkap (RAL). Ekstraksi dilakukan dengan cara maserasi menggunakan pelarut etanol 96\%. Ekstrak kental yang diperoleh diformulasikan dalam sediaan pasta gigi dengan konsentrasi $1,5 \%, 3 \%$ dan 4,5\%. Semua formula pasta gigi diuji mutu fisik kimia (organoleptik, homogenitas, $\mathrm{pH}$, viskositas dan pembentukan busa) dan aktivitas antibakteri. Data yang diperoleh pada pengujian mutu fisik kimia dianalisis secara deskriptif dan data aktivitas antibakteri dianalisis secara statistik menggunakan metode One Way ANOVA pada taraf kepercayaan 95\%, dilanjutkan dengan uji Duncan menggunakan program SPSS. Hasil pengujian antibakteri menunjukkan bahwa pasta gigi dengan konsentrasi ekstrak biji pinang 1,5\%, 3\% dan 4,5\% menunjukkan aktivitas antibakteri tehadap Streptococcus mutans dan Staphylococcus aureus. Formula pasta gigi yang efektif sebagai antibakteri terhadap bakteri uji adalah F3 dengan konsentrasi ekstrak biji pinang 4,5\% yang menghasilkan diameter daya hambat untuk Streptococcus mutans sebesar 11,37 mm dan Staphylococcus aureus sebesar 20,03 mm. Hasil pengujian mutu fisik kimia menunjukkan semua pasta gigi ekstrak biji pinang memenuhi mutu fisik kimia pasta gigi.
\end{abstract}

Kata kunci : Ekstrak biji pinang, pasta gigi, antibakteri, Streptococcus mutans, Staphylococcus aureus

\begin{abstract}
Betel nut (Areca catechu L.) is a natural material that has antibacterial activity content against Streptococcus mutans and Staphylococcus aureus. Under these conditions, betel nuts were formulated in a toothpaste that has antibacterial activity.This study aims to determine the antibacterial activity of betel nut extract in toothpaste with various concentrations of $1.5 \%, 3 \%$ and $4.5 \%$ and to determine the effective concentration of betel nut extract in toothpaste that meets the physical quality of chemical and antibacterial activity against Streptococcus mutans and Staphylococcus aureus. The research design used was a completely randomized design (CRD). Extraction was done by maceration using ethanol $96 \%$. Viscous extract obtained in the preparation of toothpaste formulated with a concentrations of $1.5 \%, 3 \%$ and $4.5 \%$. All tested formula toothpaste physical quality of chemical (organoleptic, homogeneity, $\mathrm{pH}$, viscosity and foaming) and antibacterial activity. The data obtained in the physical quality of chemical testing were analyzed descriptively and antibacterial activity data were statistically analyzed using One Way ANOVA at 95\% confidence level, followed by Duncan test using SPSS. The test results show that the antibacterial toothpaste with betel nut extract concentrations of $1.5 \%, 3 \%$ and $4.5 \%$ show antibacterial activity against Streptococcus mutans and Staphylococcus aureus. Formula toothpaste as an antibacterial effective against bacteria test is F3 with betel nut extract concentration of 4.5\%, which result in the diameter of the inhibition of Streptococcus mutans by 11.37
\end{abstract}


$\mathrm{mm}$ and $20.03 \mathrm{~mm}$ for Staphylococcus aureus. The test results show all the physical quality of chemical toothpaste betel nut extracts meet the physical quality of chemical toothpaste.

Keywords : Betel nut extracts, Toothpaste, Antibacterial, Staphylococcus aureus, Streptococcus mutans.

\section{PENDAHULUAN}

Penyakit gigi dan mulut yang banyak ditemukan pada masyarakat adalah karies gigi. Karies gigi merupakan penyakit jaringan keras gigi, yaitu email, dentin dan sementum yang disebabkan aktivitas mikroorganisme dalam meragikan karbohidrat. Hal ini ditandai dengan demineralisasi enamel. Secara normal, rongga mulut terdapat berbagai macam koloni mikroorganisme, salah satunya adalah Streptococcus mutans. Streptococcus mutans merupakan bakteri kariogenik yang dapat meragikan karbohidrat dan menghasilkan asam, bakteri ini tumbuh dalam suasana asam dan dapat menempel pada permukaan gigi. ${ }^{1}$

Salah satu cara mencegah terjadinya karies adalah dengan menggosok gigi menggunakan pasta gigi. Penambahan bahan antibakteri pada pasta gigi dapat mengurangi jumlah bakteri penyebab karies. Saat ini pasta gigi yang beredar di pasaran banyak menggunakan fluor sebagai bahan yang digunakan untuk memperkuat gigi dan menjadikan gigi lebih putih, tetapi fluor tidak dapat membunuh bakteri gigi secara efektif dan dapat menyebabkan fluorosis email pada kadar yang berlebihan. ${ }^{2}$ Diperlukan suatu produk pasta gigi yang dapat menghambat pertumbuhan bakteri penyebab karies tanpa mengurangi kualitasnya.

Salah satu bahan alam yang dapat digunakan sebagai bahan pengganti untuk mencegah karies gigi adalah biji pinang (Areca catechu L.). Biji pinang mengandung senyawa alkaloid, flavonoid, tanin, saponin, dan polifenol yang diketahui berkhasiat sebagai antibakteri. ${ }^{3}$ Beberapa penelitian menunjukkan ekstrak etanol biji pinang dapat menghambat bakteri seperti Staphylococcus aureus,
Escherchia colli, Pseudomonas aeruginosae, dan Candida albicans. Sanarto dkk, 2011 dalam penelitiannya menunjukkan bahwa ekstrak biji pinang (Areca catechu L.) dapat menghambat pertumbuhan bakteri Streptococcus mutans dengan Kadar Hambat Minimum (KHM) pada konsentrasi $1,5 \%$ yang ditandai dengan tidak adanya pertumbuhan bakteri pada media agar. ${ }^{4}$ Selain itu, Puspawati dkk, 2008 dalam penelitiannya menunjukkan bahwa ekstrak etanol biji pinang mempunyai aktivitas antibakteri terhadap bakteri uji Staphylococcus aureus dengan Konsentrasi Bunuh Minimum (KBM) adalah $1,57 \% .5$

Tujuan penelitian ini adalah untuk mengetahui aktivitas antibakteri pasta gigi ekstrak biji pinang dan untuk mengetahui konsentrasi yang efektif ekstrak biji pinang dalam pasta gigi yang memenuhi mutu fisik kimia dan memiliki aktivitas sebagai antibakteri. Rancangan penelitian yang digunakan adalah Rancangan Acak Lengkap (RAL). Data yang diperoleh pada pengujian mutu fisik kimia dianalisis secara deskriptif dan data aktivitas antibakteri diolah secara statistik dengan metode One Way ANOVA pada taraf keparcayaan $95 \%$. dilanjutkan dengan uji Duncan menggunakan program SPSS.

\section{METODE PENELITIAN}

Penelitian dilaksanakan di Laboratorium Fitokimia dan Farmakognosi STIFA Pelita Mas Palu, Laboratorium Farmasetik program studi Farmasi FMIPA Universitas Tadulako dan Laboratorium Kesehatan Palu, mulai bulan Juni sampai Agustus 2014.

\section{Alat yang digunakan}

Alat-alat gelas (Pyrex), Autoclave (Vertical Type Autoclave), Batang 
pengaduk, Bejana maserasi, Blender (Cosmos), Bunsen, Cawan petri, Cawan porselin, Cover glass, Hot plate, Inkubator, jarum ose, Laminar air flow, Lumpang dan alu, Neraca analitik (Sarltorius), Oven, Penggaris, Pipet mikroliter (Socorex), Pipet tetes, pH-meter (Consort), Vacuum rotary evaporator (Buchi R-3000), Sendok tanduk, Viskometer Brookfield, Wadah pasta gigi.

\section{Bahan yang digunakan}

Aquadest, Bakteri Streptococcus mutans, Bakteri Staphylococcus aureus, Biji pinang (Areca catechu L.), Etanol 96\%, Gliserin, Kapas steril, Kalsium karbonat, Menthol, Natrium benzoat, Natrium lauryl sulfat, Natrium Carboxymethyl Cellulose, Natrium sakarin, $\mathrm{NaCl}$ 0,9\%, Nutrien agar (NA).

\section{Penyiapan dan Determinasi Sampel}

Sampel yang digunakan adalah biji pinang (Areca catechu L.) dengan ciri-ciri buah berwarna hijau yang diperoleh dari Ampana, Kabupaten Tojo Unauna, Sulawesi Tengah dan telah dideterminasi di Herbarium UPT.Sumber Daya Hayati Sulawesi Universitas Tadulako.

\section{Pembuatan Serbuk Simplisia}

Sampel buah pinang yang digunakan dikumpulkan dan selanjutnya dilakukan sortasi basah lalu dicuci dengan air mengalir. Buah pinang yang telah dibersihkan dibelah dan bagian biji

\section{Formulasi Pasta Gigi Ekstrak Biji Pinang}

Tabel 1. Formulasi Pasta Gigi Dengan Variasi Konsentrasi Ekstrak Biji Pinang

\begin{tabular}{|c|c|c|c|c|c|}
\hline \multirow{2}{*}{ Bahan(\%) } & \multirow{2}{*}{ Fungsi } & \multicolumn{4}{|c|}{ Formula } \\
\cline { 3 - 6 } & Bahan aktif & 1,5 & 3 & 4,5 & 0 \\
\hline Ekstrak Biji Pinang & Abrasif & 45 & 45 & 45 & 45 \\
\hline Kalsium karbonat & Humektan & 25 & 25 & 25 & 25 \\
\hline Gliserin & Pengikat & 1,5 & 1,5 & 1,5 & 1,5 \\
\hline $\begin{array}{c}\text { Natrium } \\
\text { karboksimetilselulosa } \\
\text { (Na CMC) }\end{array}$ & F2 & & & \\
\hline
\end{tabular}

dipotong kecil-kecil kemudian dikeringanginkan. Simplisia yang telah kering disortasi kering dan dibuat serbuk dengan cara diblender dan diayak. Serbuk simplisia disimpan dalam wadah bersih dan tertutup rapat.

\section{Pembuatan Ekstrak Daun Kersen (Muntingia calabura L)}

Serbuk simplisia biji pinang sebanyak $600 \mathrm{~g}$ diekstraksi dengan pelarut etanol $96 \%$ menggunakan metode maserasi. Serbuk dimasukan ke dalam bejana kemudian dituangi dengan pelarut etanol $96 \%$, ditutup dan dibiarkan selama 3 x 24 jam pada suhu ruang sambil berulang-ulang diaduk agar zat aktif terekstraksi sempurna. Setelah 3 hari ekstrak disaring, kemudian residu diekstraksi kembali dengan pelarut etanol. Bejana ditutup dan dibiarkan pada suhu ruang dan terlindung dari cahaya selama 3 x 24 jam lalu disaring. Ekstrak yang diperoleh dipekatkan dengan menggunakan vacuum rotary evaporator untuk memisahkan pelarut dengan zat aktif lalu diuapkan lagi dengan menggunakan penangas air hingga diperoleh ekstrak kental biji pinang. Ekstrak kemudian ditimbang untuk mengetahui berat dan presentase ekstrak. 


\begin{tabular}{|c|c|c|c|c|c|}
\hline Natrium lauryl sulfat & Surfaktan & 1 & 1 & 1 & 1 \\
\hline Natrium benzoat & Pengawet & 0,1 & 0,1 & 0,1 & 0,1 \\
\hline Natrium sakarin & Pemanis & 0,2 & 0,2 & 0,2 & 0,2 \\
\hline Menthol & Pengaroma & 0,2 & 0,2 & 0,2 & 0,2 \\
\hline Aquadest & Pelarut & ad 100 & ad 100 & ad 100 & ad 100 \\
\hline
\end{tabular}

Keterangan :

F1 : Formula pasta gigi ekstrak biji pinang dengan konsentrasi $1,5 \%$

F2 : Formula pasta gigi ekstrak biji pinang dengan konsentrasi 3\%

F3 : Formula pasta gigi ekstrak biji pinang dengan konsentrasi $4,5 \%$

F4 : Formula pasta gigi tanpa ekstrak biji pinang

\section{Prosedur pembuatan Pasta gigi}

Menimbang bahan aktif ekstrak biji pinang dengan variasi konsentrasi 1,5\%, 3\%, dan $4,5 \%$ dan bahan tambahan kalsium karbonat, gliserin, natrium karboksimetilselulosa ( $\mathrm{Na} \mathrm{CMC}$ ), natrium lauryl sulfat, natrium benzoat, natrium sakarin, menthol dan aquadest. Melarutkan $\mathrm{Na} \mathrm{CMC}$ dalam air panas didiamkan selama 15 menit, setelah itu diaduk homogen sebagai massa 1. Menggerus kalsium karbonat, dan menambahkan sodium lauryl sulfat gerus homogen, kemudian menambahkannya pada massa 1 menjadi campuran sambil digerus homogen sebagai massa 2. Melarutkan ekstrak etanol biji pinang dengan gliserin diaduk homogen dan menambahkan pada massa 2 sambil digerus sampai homogen. Melarutkan natrium benzoat dan natrium sakarin kedalam sisa air dan diaduk sampai larut sempurna. Kemudian ditambahkan pada massa 2 digerus homogen sampai terbentuk massa pasta. Menambahkan menthol ke dalam massa pasta, digerus sampai homogen, kemudian memasukkan pasta kedalam tube.

\section{Pengujian Mutu Fisik Kimia Pasta Gigi}

Pengujian mutu fisik kimia sediaan pasta gigi ekstrak biji pinang dilakukan dengan beberapa pengujian antara lain :

1. Uji organoleptik

Pengamatan organoleptik pasta gigi meliputi bentuk, warna, dan aroma yang diamati secara obyektif. Pengamatan ini bertujuan untuk melihat terjadinya perubahan secara signifikan pada sediaan yang telah dibuat. Pengujian dilakukan setiap minggu selama 3 minggu penyimpanan.

\section{Uji homogenitas}

Pengujian homogenitas dilakukan dengan cara pasta gigi yang akan diuji dioleskan pada gelas obyek untuk diamati homogenitasnya. Apabila tidak terdapat butiran-butiran kasar diatas gelas obyek tersebut, maka pasta gigi yang diuji dinyatakan homogen, sedangkan adanya butiran-butiran kasar menunjukkan bahwa pasta gigi tidak homogen. Pengujian dilakukan setiap minggu selama 3 minggu penyimpanan.

3. Uji keasaman $(\mathrm{pH})$

Pengukuran $\mathrm{pH}$ dilakukan dengan cara mencelupkan alat $\mathrm{pH}$ meter kedalam sediaan pasta sampai menunjukan angka yang konstan setelah beberapa saat. Nilai $\mathrm{pH}$ didapatkan dari angka tersebut. Pengujian dilakukan setiap minggu selama 3 minggu penyimpanan.

4. Uji viskositas

Penentuan viskositas dilakukan dengan menggunakan alat Viskometer Brookfield menggunakan spindel nomor 6 dan dan pada kecepatan $2 \mathrm{rpm}$, memasang spindel pada gantungan spindel kemudian menurunkan spindel sedemikian rupa hingga tercelup kedalam sampel. Dibiarkan spindel berputar dan dibaca angka yang ditunjukkan oleh jarum merah tersebut untuk menghitung viskositas. Pengujian dilakukan setiap minggu selama 3 minggu penyimpanan.

5. Uji pembentukan busa

Uji pembentukan busa dilakukan dengan cara membuat larutan $1 \%$ dari berbagai konsentrasi pasta gigi ekstrak biji pinang dalam air. Kemudian dimasukan kedalam gelas ukur berpenutup, lalu dikocok 
selama 1 menit. Kemudian mengukur tinggi busa yang terbentuk. Pengujian dilakukan setiap minggu selama 3 minggu penyimpanan.

\section{Uji Aktivitas Antibakteri Pasta Gigi Ekstrak Biji Pinang}

1. Sterilisasi Alat dan Bahan

Sterilisasi dilakukan dengan cara yang sesuai terhadap masing-masing alat. Alat-alat yang disterilkan harus dalam keadaan bersih dan kering. Tabung reaksi, gelas ukur, erlenmeyer, cawan petri ditutup mulutnya dengan kapas lalu aluminium foil. Kemudian disterilkan dalam oven pada suhu $180{ }^{\circ} \mathrm{C}$, selama 2 jam. Medium pembenihan dan larutan $\mathrm{NaCl}$ distrerilisasi dengan autoklaf pada suhu $121^{\circ} \mathrm{C}$ selama 30 menit. Pinset dan jarum ose disterilkan dengan cara dipijarkan pada nyala bunsen.

2. Pembuatan medium nutrien agar (NA)

Menimbang medium Nutrien Agar (NA) sebanyak 2,3 gram dilarutkan dalam $100 \mathrm{ml}$ aquadest menggunakan erlenmeyer. Media dihomogenkan diatas penangas air sampai media Nutrien Agar benar-benar larut. Larutan tersebut kemudian disterilkan dalam autoklaf pada suhu $121{ }^{0} \mathrm{C}$ selama 15 menit. Disimpan pada lemari pendingin, dan dipanaskan kembali ketika digunakan.

3. Penyiapan Bakteri Uji

Bakteri uji Streptococcus mutans dan Staphylococcus aureus yang berasal dari biakan murni, masing-masing diambil 1 ose lalu diinokulasikan dengan cara digoreskan pada medium Nutrien Agar (NA) miring. Setelah itu diinkubasi pada suhu $37^{\circ} \mathrm{C}$ selama 24 jam.

Biakkan bakteri diambil dengan jarum ose steril lalu disuspensikan kedalam tabung reaksi yang berisi $10 \mathrm{ml}$ larutan $\mathrm{NaCl} 0,9 \%$ sampai didapat kekeruhan suspensi bakteri yang sama dengan kekeruhan standar Mc.Farland, ini berarti konsentrasi suspensi bakteri adalah $10^{8} \mathrm{CFU} / \mathrm{ml}$. Konsentrasi suspensi bakteri $10^{8} \mathrm{CFU} / \mathrm{ml}$ yang digunakan pada pengujian aktivitas antibakteri.

4. Uji Aktivitas Antibakteri Pasta Gigi Ekstrak Biji Pinang

Uji daya antibakteri pada penelitian ini menggunakan metode difusi dengan cara sumuran. Prosedur yang dilakukan adalah Menyiapkan medium Nutrien Agar (NA) yang telah disterilkan dalam autoklaf suhu $121^{\circ} \mathrm{C}$ selama 15 menit. Kemudian dalam keadaan masih hangat nutrien agar dituangkan pada 10 cawan petri steril berukuran $9 \mathrm{~cm}$ sebanyak $15 \mathrm{ml}$, lalu didiamkan hingga padat. Menyiapkan suspensi bakteri Streptococcus mutans dan Staphylococcus aureus yang telah diinokulasikan dalam $\mathrm{NaCl} 0,9 \%$, lalu mencelupkan kapas steril ke dalam suspensi bakteri kemudian dioleskan pada medium NA. Membuat sumuran (lubang) pada medium nutrien agar menggunakan alat tips diameter $7 \mathrm{~mm}$, kemudian menyiapkan sampel pasta gigi sebanyak $0,1 \mathrm{~g}$ pada variasi konsentrasi $1,5 \%, 3 \%, 4,5 \%$, kontrol negatif dan kontrol positif. Pengujian dilakukan dengan cara memasukkan pasta gigi dengan berbagai konsentrasi masing-masing sebanyak $0,1 \mathrm{~g}$ ke dalam sumuran, kemudian cawan petri diinkubasi selama 24 jam pada suhu $37^{\circ} \mathrm{C}$. Pengukuran dilakukan pada zona bening yang terbentuk disekeliling sumuran yang menunjukkan zona hambat pertumbuhan bakteri.

\section{Analisis Data}

Rancangan penelitian yang digunakan pada penelitian ini adalah Rancanagan Acak Lengkap (RAL). Data yang diperoleh pada pengujian mutu fisik kimia dianalisis secara deskriptif dan data aktivitas antibakteri diolah secara statistik dengan metode One Way ANOVA pada taraf kepercayaan $95 \%$ dilanjutkan dengan uji Duncan menggunakan program SPSS.

\section{HASIL DAN PEMBAHASAN Hasil penelitian Pengujian Fitokimia}

Tabel 2 Hasil Pengujian fitokimia ekstrak biji pinang

\begin{tabular}{|c|c|}
\hline Kandungan kimia & Keterangan \\
\hline Alkaloid & + \\
\hline flavonoid & + \\
\hline tanin & + \\
\hline saponin & + \\
\hline Polifenol & + \\
\hline
\end{tabular}


Ket: (+) : Mengandung senyawa yang

diuji

Tabel 3 Hasil Pengujian Organoleptik Pasta Gigi Ekstrak Biji Pinang

\begin{tabular}{|c|c|c|c|c|}
\hline \multirow{2}{*}{$\begin{array}{c}\text { Formul } \\
\mathbf{a} \\
\end{array}$} & \multicolumn{4}{|c|}{ Pengamatan Organoleptik } \\
\hline & Hari ke-1 & Hari ke-7 & Hari ke-14 & Hari ke-21 \\
\hline F1 & $\begin{array}{c}\text { Krem, aroma } \\
\text { menthol, agak } \\
\text { kental }\end{array}$ & $\begin{array}{l}\text { Krem, aroma } \\
\text { menthol, agak } \\
\text { kental }\end{array}$ & $\begin{array}{l}\text { Krem, aroma } \\
\text { menthol, agak } \\
\text { kental }\end{array}$ & $\begin{array}{l}\text { Krem, aroma } \\
\text { menthol, agak } \\
\text { kental }\end{array}$ \\
\hline F2 & $\begin{array}{c}\text { Krem } \\
\text { kecoklatan, } \\
\text { aroma menthol, } \\
\text { kental }\end{array}$ & $\begin{array}{c}\text { Krem } \\
\text { kecoklatan, } \\
\text { aroma menthol, } \\
\text { kental }\end{array}$ & $\begin{array}{c}\text { Krem } \\
\text { kecoklatan, } \\
\text { aroma menthol, } \\
\text { kental }\end{array}$ & $\begin{array}{c}\text { Krem } \\
\text { kecoklatan, } \\
\text { aroma menthol, } \\
\text { kental }\end{array}$ \\
\hline F3 & $\begin{array}{l}\text { Coklat, aroma } \\
\text { menthol, sangat } \\
\text { kental }\end{array}$ & $\begin{array}{r}\text { Coklat, a } \\
\text { menthol, } \\
\text { kent }\end{array}$ & $\begin{array}{l}\text { Coklat, aroma } \\
\text { menthol, sangat } \\
\text { kental }\end{array}$ & $\begin{array}{l}\text { Coklat, aroma } \\
\text { menthol, sangat } \\
\text { kental }\end{array}$ \\
\hline F4 & $\begin{array}{l}\text { Putih, aroma } \\
\text { menthol, agak } \\
\text { lembek }\end{array}$ & $\begin{array}{l}\text { Putih, aroma } \\
\text { menthol, agak } \\
\text { lembek }\end{array}$ & $\begin{array}{c}\text { Putih, aroma } \\
\text { menthol, agak } \\
\text { lembek }\end{array}$ & $\begin{array}{l}\text { Putih, aroma } \\
\text { menthol, agak } \\
\text { lembek }\end{array}$ \\
\hline
\end{tabular}

Tabel 4 Hasil uji homogenitas pasta gigi ekstrak biji pinang

\begin{tabular}{|c|l|l|l|c|}
\hline \multirow{2}{*}{ Formula } & \multicolumn{4}{|c|}{ Pengamatan } \\
\cline { 2 - 5 } & Hari ke-1 & Hari ke-7 & Hari ke-14 & Hari ke-21 \\
\hline F1 & Homogen & Homogen & Homogen & Homogen \\
\hline F2 & Homogen & Homogen & Homogen & Homogen \\
\hline F3 & Homogen & Homogen & Homogen & Homogen \\
\hline F4 & Homogen & Homogen & Homogen & Homogen \\
\hline
\end{tabular}

Tabel 5 Hasil uji pH pasta gigi ekstrak biji pinang

\begin{tabular}{|c|c|c|c|c|}
\hline \multirow{2}{*}{$\begin{array}{c}\text { Formul } \\
\text { a }\end{array}$} & \multicolumn{4}{|c|}{ Rerata pH pasta gigi } \\
\cline { 2 - 5 } & $\begin{array}{c}\text { Hari } \\
\text { ke-1 }\end{array}$ & $\begin{array}{c}\text { Hari } \\
\text { ke-7 }\end{array}$ & $\begin{array}{c}\text { Hari } \\
\text { ke-14 }\end{array}$ & $\begin{array}{c}\text { Hari } \\
\text { ke-21 }\end{array}$ \\
\hline F1 & 7,03 & 6,97 & 7,12 & 7,17 \\
\hline F2 & 6,90 & 6,83 & 6,92 & 7,02 \\
\hline F3 & 6,77 & 6,85 & 6,97 & 7,07 \\
\hline F4 & 7,18 & 6,92 & 6,77 & 7,55 \\
\hline
\end{tabular}


Tabel 6 Hasil Uji Viskositas Pasta Gigi Ekstrak Biji Pinang

\begin{tabular}{|c|c|c|c|c|}
\hline \multirow{2}{*}{$\begin{array}{c}\text { Formul } \\
\text { a }\end{array}$} & \multicolumn{4}{|c|}{ Rerata Viskositas (Cp) } \\
\cline { 2 - 5 } & $\begin{array}{c}\text { Hari } \\
\text { ke-1 }\end{array}$ & $\begin{array}{c}\text { Hari } \\
\text { ke-7 }\end{array}$ & $\begin{array}{c}\text { Hari } \\
\text { ke-14 }\end{array}$ & $\begin{array}{c}\text { Hari } \\
\text { ke-21 }\end{array}$ \\
\hline F1 & $\begin{array}{c}222.0 \\
00\end{array}$ & $\begin{array}{c}226.3 \\
33\end{array}$ & $\begin{array}{c}231.6 \\
66\end{array}$ & $\begin{array}{c}236.3 \\
33\end{array}$ \\
\hline F2 & $\begin{array}{c}312.3 \\
33\end{array}$ & $\begin{array}{c}323.3 \\
33\end{array}$ & $\begin{array}{c}337.0 \\
00\end{array}$ & $\begin{array}{c}350.6 \\
66\end{array}$ \\
\hline F3 & $\begin{array}{c}404.6 \\
66\end{array}$ & $\begin{array}{c}423.3 \\
33\end{array}$ & $\begin{array}{c}434.3 \\
33\end{array}$ & $\begin{array}{c}443.6 \\
66\end{array}$ \\
\hline F4 & $\begin{array}{c}196.0 \\
00\end{array}$ & $\begin{array}{c}207.3 \\
33\end{array}$ & $\begin{array}{c}220.3 \\
33\end{array}$ & $\begin{array}{c}232.0 \\
00\end{array}$ \\
\hline
\end{tabular}

Tabel 7 Hasil Uji Pembentukan Busa Pasta Gigi Ekstrak Biji Pinang

\begin{tabular}{|c|c|c|c|c|}
\hline \multirow{2}{*}{$\begin{array}{c}\text { Formu } \\
\text { la }\end{array}$} & \multicolumn{4}{|c|}{$\begin{array}{c}\text { Rerata pembentukan busa } \\
\text { selama penyimpanan }\end{array}$} \\
\cline { 2 - 5 } & $\begin{array}{c}\text { Hari } \\
\text { ke-1 }\end{array}$ & $\begin{array}{c}\text { Hari } \\
\text { ke-7 }\end{array}$ & $\begin{array}{c}\text { Hari } \\
\text { ke-14 }\end{array}$ & $\begin{array}{c}\text { Hari } \\
\text { ke-21 }\end{array}$ \\
\hline F1 & 27,33 & 25,66 & 25 & 24,33 \\
\hline F2 & 22 & 20,66 & 19,33 & 18 \\
\hline F3 & 19,66 & 18 & 16 & 15,33 \\
\hline F4 & 50 & 50,33 & 48,33 & 47,66 \\
\hline
\end{tabular}

Tabel 8 Hasil Pengujian Daya Hambat Pasta Gigi Ekstrak Biji Pinang Terhadap Streptococcus mutans

\begin{tabular}{|c|c|c|c|c|}
\hline \multirow{2}{*}{ Formula } & \multicolumn{3}{|c|}{$\begin{array}{c}\text { Diameter hambat } \\
\text { antibakteri (mm) }\end{array}$} & \multirow{2}{*}{$\begin{array}{c}\text { Rera } \\
\text { ta }\end{array}$} \\
\cline { 2 - 4 } & A & B & C & \\
\hline Formula 1 & 8,79 & 9,04 & 9,54 & $9,12^{\mathrm{a}}$ \\
\hline Formula 2 & $\begin{array}{c}10,2 \\
9\end{array}$ & $\begin{array}{c}10,5 \\
4\end{array}$ & 10,04 & $\begin{array}{c}10,29 \\
\text { b }\end{array}$ \\
\hline Formula 3 & $\begin{array}{c}11,2 \\
9\end{array}$ & $\begin{array}{c}11,0 \\
4\end{array}$ & 11,79 & $\begin{array}{c}11,37 \\
\text { c }\end{array}$ \\
\hline $\begin{array}{c}\text { Kontrol } \\
\text { positif }\end{array}$ & 24 & 24 & 24 & $24^{\mathrm{d}}$ \\
\hline
\end{tabular}

Ket : Abjad yang berbeda menunjukkan adanya perbedaan yang signifikan 
Tabel 9 Hasil Pengujian Daya Hambat Pasta Gigi Ekstrak Biji Pinang Terhadap Staphylococcus aureus

\begin{tabular}{|c|c|c|c|c|}
\hline \multirow{2}{*}{ Formula } & \multicolumn{3}{|c|}{$\begin{array}{c}\text { Diameter hambat } \\
\text { antibakteri (mm) }\end{array}$} & \multirow{2}{*}{$\begin{array}{c}\text { Rera } \\
\text { ta }\end{array}$} \\
\cline { 2 - 4 } & $\mathbf{A}$ & $\mathbf{B}$ & $\mathbf{C}$ & \\
\hline Formula 1 & $\begin{array}{c}17,2 \\
8\end{array}$ & $\begin{array}{c}17,0 \\
3\end{array}$ & 17,53 & $\begin{array}{c}17,28 \\
\mathrm{a}\end{array}$ \\
\hline Formula 2 & $\begin{array}{c}18,5 \\
3\end{array}$ & $\begin{array}{c}18,7 \\
8\end{array}$ & 18,78 & $\begin{array}{c}18,69 \\
\mathrm{~b}\end{array}$ \\
\hline Formula 3 & $\begin{array}{c}20,0 \\
3\end{array}$ & $\begin{array}{c}20,2 \\
8\end{array}$ & 19,78 & $\begin{array}{c}20,03 \\
\mathrm{c}\end{array}$ \\
\hline $\begin{array}{c}\text { Kontrol } \\
\text { positif }\end{array}$ & 23 & 22 & 20,5 & $\begin{array}{c}21,83 \\
\mathrm{~d}\end{array}$ \\
\hline & & & & \\
\hline
\end{tabular}

Ket : Abjad yang berbeda menunjukkan adanya perbedaan yang signifikan

\section{Pembahasan}

Pengujian fitokimia pada penelitian ini dilakukan untuk mengetahui senyawa kimia yang terkandung dalam ekstrak biji pinang yang digunakan sebagai zat aktif dalam pembuatan sediaan pasta gigi. Hasil pengujian fitokimia menunjukkan bahwa ekstrak biji pinang positif mengandung senyawa alkaloid, flavonoid, tanin, saponin dan polifenol.

Formulasi sediaan pasta gigi ekstrak biji pinang dibuat dengan 3 konsentrasi yaitu 1,5\%,3\% dan 4,5\% serta formula pasta gigi tanpa ekstrak dibuat sebagai kontrol negatif. Evalusi mutu fisik kimia pasta gigi ekstrak biji pinang meliputi uji organoleptik, uji homogenitas, uji $\mathrm{pH}$, uji viskositas, dan uji pembentukan busa. Pengujian dilakukan selama 21 hari penyimpanan dengan pengujian pada hari ke-1, 7, 14, dan 21.

Pengujian organoleptik menunjukan bahwa semakin tinggi konsentrasi ekstrak biji pinang yang digunakan maka warna pasta gigi yang dihasilkan semakin coklat (pekat). Perbedaan konsentrasi ekstrak biji pinang juga mempengaruhi bentuk atau tekstur pasta gigi, dimana semakin meningkatnya konsentrasi ekstrak maka pasta gigi akan semakin kental. Perbedaan konsentrasi ekstrak tidak mempengaruhi aroma pasta gigi ekstrak biji pinang. Aroma pasta gigi pada semua formula menunjukan aroma yang sama yaitu berbau menthol. Kemungkinan disebabkan karena kosentrasi ekstrak biji pinang yang digunakan rendah dan aroma tajam dari menthol dapat menutupi aroma khas biji pinang sehingga tidak terdapat perbedaan aroma pasta gigi.

Pengujian homogenitas pasta gigi F1, F2, F3, dan F4 tidak terlihat adanya partikel-partikel kasar sehingga menghasilkan sediaan pasta gigi yang homogen. Hal ini menunjukkan bahwa semua bahan tambahan dan ekstrak sebagai zat aktif yang digunakan dalam pembuatan pasta gigi tercampur secara merata. Pasta gigi ekstrak biji pinang memiliki sifat fisik yang baik dalam berbagai konsentrasi dengan homogenitas tetap baik selama 21 hari penyimpanan.

Pengujian $\mathrm{pH}$ selama 21 hari penyimpanan nilai $\mathrm{pH}$ pasta gigi $\mathrm{F} 1, \mathrm{~F} 2$, dan $\mathrm{F} 3$ masih masuk dalam persyaratan $\mathrm{pH}$ untuk pasta gigi yaitu berkisar antara 4,510,5. Pengujian $\mathrm{pH}$ pasta gigi ekstrak biji pinang menunjukkan bahwa semakin tinggi konsentrasi ekstrak pada pasta gigi maka semakin rendah $\mathrm{pH}$ pasta gigi ekstrak biji pinang dan kemungkinan 
disebabkan karena senyawa-senyawa kimia yang terkandung dalam ekstrak biji pinang seperti flavonoid, tanin dan polifenol memiliki $\mathrm{pH}$ asam sehingga ekstrak biji pinang cenderung memiliki $\mathrm{pH}$ asam. Nilai $\mathrm{pH}$ pasta gigi ekstrak biji pinang selama penyimpanan 21 hari mengalami perubahan $\mathrm{pH}$ pada masingmasing formula, tetapi masih masuk dalam standar persyaratan $\mathrm{pH}$ pasta gigi bedasarkan SNI. Perubahan nilai $\mathrm{pH}$ pada masing-masing formula disebabkan karena faktor lingkungan seperti perubahan suhu karena penyimpanan dilakukan pada suhu ruang serta wadah penyimpanan yang kurang kedap sehingga memungkinkan udara dapat masuk.

Pengujian viskositas selama penyimpanan 21 hari menunjukkan bahwa semakin tinggi konsentrasi ekstrak yang digunakan dalam pasta gigi maka viskositas pasta gigi yang dihasilkan semakin tinggi dan kemungkinan disebabkan karena meningkatnya konsentrasi ekstrak dalam pasta gigi, menyebabkan berkurangnya jumlah air dalam pasta gigi sehingga dalam mengembangkan $\mathrm{Na} \mathrm{CMC}$ membutuhkan air yang lebih sedikit dan menghasilkan pasta gigi yang lebih kental. Penyimpanan 21 hari pasta gigi ekstrak biji pinang mengalami peningkatan nilai viskositas pada masing-masing formula, tetapi semua formula pasta gigi ekstrak biji pinang memenuhi standar viskositas pasta gigi yaitu mudah dikeluarkan dari tube, cukup keras sehingga dapat mempertahankan bentuk pasta minimal 1 menit.

Pengujian pembentukan busa selama penyimpanan 21 hari menunjukan semakin tinggi konsentrasi ekstrak biji pinang yang digunakan dalam pasta gigi maka semakin sedikit busa yang dihasilkan dan semakin rendah konsentrasi ekstrak yang digunakan maka busa yang dihasilkan akan semakin banyak dan kemungkinan disebabkan karena konsentrasi natrium lauryl sulfat yang digunakan sebagai surfaktan tetap sama yaitu $1 \%$ sehingga jumlah natrum lauryl sulfat tidak cukup untuk mengemulsi ekstrak.

Pengujian antibakteri pasta gigi ekstrak biji pinang dilakukan untuk mengetahui daya hambat ekstrak biji pinang yang diformulasikan dalam sediaan pasta gigi. Bakteri yang digunakan adalah Streptococcus mutans dan Staphylococcus aureus. Pengujian dilakukan dengan menggunakan metode difusi agar dengan cara sumuran. Pasta gigi F1 dengan konsentrasi ekstrak biji pinang 1,5\%, F2 dengan konsentrasi ekstrak biji pinang 3\%, F3 dengan konsentrasi ekstrak biji pinang 4,5\%, F4 pasta gigi tanpa ekstrak biji pinang (kontrol negatif) dan kontrol positif pasta gigi herbal dari PT. Unilever yang beredar di pasaran.

Berdasarkan hasil data statistik menggunakan One Way ANOVA yang dilanjutkan dengan uji Duncan, pengujian aktivitas antibakteri pasta gigi ekstrak biji pinang terhadap bakteri Streptococcus mutans untuk pasta gigi dengan konsentrasi ekstrak biji pinang 1,5\% menghasilkan diameter daya hambat 9,12 $\mathrm{mm}$. Diameter daya hambat pasta gigi dengan konsentrasi ekstrak biji pinang 3\% adalah 10,29 $\mathrm{mm}$ dan diameter daya hambat pasta gigi dengan konsentrasi ekstrak biji pinang 4,5\% adalah $11,37 \mathrm{~mm}$. Hasil ini menunjukkan bahwa semakin tinggi konsentrasi biji pinang dalam pasta gigi maka diameter daya hambat antibakteri akan semakin besar. Hal ini disebabkan karena semakin tinggi konsentrasi bahan uji, yang berarti semakin besar jumlah zat aktif yang terkandung dalam ekstrak, maka semakin besar pula kemampuan bahan uji dalam menghambat pertumbuhan suatu bakteri. ${ }^{6}$ Diameter daya hambat untuk kontrol positif adalah $24 \mathrm{~mm}$. Hasil diameter daya hambat pasta gigi ekstrak biji pinang pada semua formula pasta gigi ekstrak biji pinang masih belum sebanding dengan pasta gigi herbal yang beredar di pasaran (kontrol positif) dalam menghambat 
bakteri Streptococcus mutans, tetapi semua formula pasta gigi ekstrak biji pinang telah menunjukkan aktivitas sebagai antibakteri karena suatu bahan baru dapat dikatakan memiliki aktivitas antibakteri bila diameter hambatan yang terbentuk adalah lebih dari atau sama dengan $6 \mathrm{~mm}$ (Depkes RI, 1989). ${ }^{2}$ Selain itu, menurut Davis Stout kriteria kekuatan daya antibakteri adalah diameter zona hambat $5 \mathrm{~mm}$ atau kurang dikategorikan lemah, zona hambat 5-10 $\mathrm{mm}$ dikategorikan sedang, zona hambat 10-20 mm dikategorikan kuat dan zona hambat $20 \mathrm{~mm}$ atau lebih dikategorikan sangat kuat. ${ }^{7}$ Berdasarkan kriteria tersebut, maka kemampuan antibakteri pasta gigi ekstrak biji pinang terhadap Streptococcus mutans dengan konsentrasi ekstrak 1,5\% $(9,12 \mathrm{~mm})$ memiliki daya antibakteri sedang dan konsentrasi ekstrak 3\% (10,29 $\mathrm{mm}), 4,5 \%(11,37 \mathrm{~mm})$ memiliki daya antibakteri kuat.

Pengujian aktivitas antibakteri pasta gigi ekstrak biji pinang terhadap bakteri Staphylococcus aureus, diameter daya hambat pasta gigi dengan konsentrasi ekstrak biji pinang 1,5\% adalah 17,28 mm. Diameter daya hambat pasta gigi dengan konsentrasi ekstrak 3\% adalah 18,69 mm dan diameter daya hambat untuk pasta gigi dengan konsentrasi ekstrak 4,5\% adalah 20,03 mm. Hasil ini menunjukkan menunjukkan semakin tinggi konsentrasi biji pinang dalam pasta gigi maka diameter daya hambat terhadap bakteri Staphylococcus aureus semakin besar. Hal ini disebabkan karena semakin tinggi konsentrasi bahan uji, yang berarti semakin besar jumlah zat aktif yang terkandung dalam ekstrak, maka semakin besar pula kemampuan bahan uji dalam menghambat pertumbuhan suatu bakteri. ${ }^{6}$ Diameter daya hambat untuk kontrol positif adalah $21,83 \mathrm{~mm}$. Hasil diameter daya hambat pasta gigi dengan ekstrak biji pinang 4,5\% hampir sebanding dengan pasta gigi herbal yang beredar di pasaran (kontrol positif). Kemampuan daya antibakteri pasta gigi ekstrak biji pinang terhadap Staphylococcus aureus dengan konsentrasi ekstrak 1,5\% (17,28 mm), 3\% $(18,69 \mathrm{~mm})$ dan $4,5 \% \quad(20,03 \mathrm{~mm})$ memiliki daya antibakteri kuat.

Aktivitas antibakteri dari pasta gigi ekstrak biji pinang disebabkan adanya senyawa-senyawa kimia yang terdapat dalam ekstrak biji pinang seperti alkaloid, flavonoid, tanin, saponin dan polifenol. Alkaloid memiliki kemampuan sebagai antibakteri dengan cara mengganggu komponen penyusun peptidoglikan pada sel bakteri, sehingga lapisan dinding sel tidak terbentuk secara utuh dan menyebabkan kematian sel tersebut. Flavonoid berfungsi sebagai antibakteri dengan cara membentuk senyawa kompleks terhadap protein ekstraseluler yang menyebabkan rusaknya susunan dan perubahan mekanisme membran sel bakteri. Tanin diduga dapat mengkerutkan dinding sel atau membran sel sehingga mengganggu permeabilitas sel itu sendiri. Akibat terganggunya permeabilitas, sel tidak dapat melakukan aktivitas hidup sehingga pertumbuhannya akan terhambat atau bahkan mati. ${ }^{8}$ Saponin dengan cara menurunkan tegangan permukaan sehingga mengakibatkan naiknya permeabilitas atau kebocoran sel dan mengakibatkan senyawa intraseluler akan keluar. ${ }^{9}$ Polifenol berpotensi sebagai antibakteri dengan meracuni protoplasma, merusak dan menembus dinding sel serta mengendapkan protein sel bakteri. ${ }^{10}$

Kontrol negatif pada pengujian antibakteri ini memberikan daya hambat terhadap bakteri Streptococcus mutans dan Staphylococcus aureus dengan diameter daya hambat masing-masing adalah 20,26 $\mathrm{mm}$ dan $21,22 \mathrm{~mm}$, tetapi hasil yang diperoleh tidak sebanding dengan daya hambat pada tiap formula pasta gigi ekstrak biji pinang. Daya hambat yang diperoleh pada kontrol negatif disebabkan karena pasta gigi menggunakan natrium benzoat sebagai pengawet. Data diameter daya hambat yang diperoleh merupakan selisih antara diameter daya hambat sediaan pasta gigi ekstrak biji pinang 
dengan sediaan pasta gigi tanpa ekstrak (kontrol negatif).

Berdasarkan hasil penelitian yang diperoleh maka dapat disimpulkan bahwa pasta gigi ekstrak biji pinang memiliki aktivitas antibakteri terhadap bakteri Streptococcus mutans dan Staphylococcus aureus. Formula pasta gigi yang efektif sebagai antibakteri tehadap bakteri uji adalah F3 dengan konsentrasi ekstrak biji pinang 4,5\% yang menghasilkan diameter daya hambat untuk streptococcus mutans sebesar $11,37 \mathrm{~mm}$ dan staphylococcus aureus sebesar 20,03 mm. Hasil pengujian mutu fisik kimia menunjukkan semua pasta gigi ekstrak biji pinang memenuhi mutu fisik kimia pasta gigi.

\section{DAFTAR PUSTAKA}

1. Kidd, E dan Bechal, S. 1992. DasarDasar Karies, Penyakit dan Penangulangannya. Buku Kedokteran EGC. Jakarta. Hal:1-4, 153-155

2. Bayuarti, Y. 2006. Kajian proses pembuatan pasta gigi gambir (Uncaria gambir roxb) sebagai antibakteri. [skripsi]. Fakultas Teknologi Pertanian. Institut Pertanian Bogor. Bogor. Hal:2

3. Widyanigrum, H. 2011. Kitab Tanaman Obat Nusantara. MedPress. Yogyakarta. Hal:418-420

4. Sanarto Santoso, Kuni Ridha Andini dan Hirzi Asdyaksa. 2011. Efektivitas ekstrak etanol biji pinang (Areca catechu L.) terhadap pertumbuhan bakteri Streptococcus mutans secara in vitro. Fakultas Kedokteran Gigi Universitas Brawijaya. Hal:1-4
5. Puspawati, N. 2008. Uji aktivitas antibakteri ekstrak etanolik biji pinang (Areca catechu L.) terhadap Staphylococcus aureus ATCC 25923 dan Pseudomonas aeruginosa ATCC 2785. Fakultas Ilmu Kesehatan Universitas Setia Budi. Hal:1-3

6. Adrianto, A. 2012. Uji daya antibakteri ekstrak daun salam (Eugenia polyantha Wight) dalam pasta gigi terhadap pertumbuhan Streptococcus mutans. [skripsi]. Fakultas Kedokteran Gigi Universitas Jember. Jember. Hal:16-17

7. Rahmi Adila, Nurmiati dan Anthoni Agustien. 2013. Uji Antimikroba Curcuma spp. Terhadap Pertumbuhan Candida albicans, Staphylococcus aureus dan Escherichia coli. Jurnal Biologi Universitas Andalas Vol.2 No.1. Hal:5-6

8. Aulia Abdul Hamid, Helmie Bafadal dan Lisa Puspita Sari. 2011. Uji efektivitas ekstrak etanol biji pinang (Areca catechu L.) terhadap pertumbuhan bakteri methicilinresistant Staphylococcus aureus (MRSA) secara in vitro. Fakultas Kedokteran Universitas Brawijaya. Hal:2-4

9. Robinson, T. 1995. Kandungan Organik Tumbuhan Tingkat Tinggi. Institut Tekhnologi Bandung. Bandung. Hal:283,285

10. Adrianto, K. 2012. Efek Antibakteri Polifenol Biji Kakao Pada Streptococcus Mutans. [skripsi]. Fakultas Kedokteran Gigi Universitas Jember. Jember. Hal:45-46 